Tạp chi Khoa học và Công nghệ, Số 30, 2017

\title{
PERFORMANCE OF SEISMICALLY ISOLATED BUILDINGS USING SFP BEARING: AN APPLICATION IN VIETNAM
}

\author{
NAM V. NGUYEN ${ }^{1}$, HOA P. HOANG ${ }^{2}$, THAN T. HUA ${ }^{3}$ \\ ${ }^{1}$ Department of Civil Engineering, Industrial University of Ho Chi Minh City, \\ ${ }^{2}$ The University of Danang, University of Science and Technology, \\ ${ }^{3}$ Southern Institute of Water Resources Research; \\ nguyenvannam@iuh.edu.vn,phuonghoabkdn@gmail.com,huathan020608@gmail.com
}

\begin{abstract}
At present, the use of structural vibration control technology in the design of earthquake resistant in Vietnam is very limited. In this paper, a performance evaluation of using single friction pendulum bearing (SFP) for earthquake resistant buildings with earthquake conditions in Vietnam is presented. A one-dimensional (1-D) model of a 5-storey building subjected to earthquakes was developed for time history analysis. Accordingly, the model is analyzed in two configurations: with and without SFP bearing. The ground acceleration data was selected and scaled to fit the design acceleration in Hanoi determined from TCVN 9386:2012. The dynamic responses of the two configurations was evaluated in detail. It is shown that the seismically isolated configuration can reduce the base shear up to $90 \%$. A significant decrease in the inter-story drift and absolute floor acceleration was also observed.
\end{abstract}

Keywords. Base isolation techniques, SFP bearing, earthquake - resistant design, passive control of structure, seismic conditions in Hanoi.

\section{INTRODUCTION}

Earthquake is one of the major human dangers and the main cause of damage, collapse of construction. Historically, there were many strong earthquakes occurring in many countries such as: Kanto (Japan, 1923), Sichuan (China, 2008)..., it has killed so many human lives, causing heavy losses to their economies. Earthquake resistant design is an important requirement for designers. Although Vietnam does not locate in a strong earthquake zone, there has been strong earthquakes occurred. Recently, the earthquakes in Vietnam happen more often [6], and earthquake in Hanoi is predicted up to Level 8 [10]. Currently, the design of earthquake resistant buildings in Vietnam is a mandatory requirement but it is still the traditional design. In this study, seismic base isolation technology with SFP bearing for earthquake resistant building in Vietnam is presented. This is a modern design perspective.

Base isolation is a passive structural control technology, and is an effective approach to mitigate the damage caused by earthquakes to the structures. Recently, it has been studied and applied very commonly in developed countries such as USA, Japan.... The main idea of this technique is to isolate the superstructure from the ground using flexible bearings, called seismic isolation bearings. It has a small horizontal stiffness and it is typically inserted between the foundation and superstructure to isolate the structure from the ground movement, limiting the earthquake energy transferred to the superstructure. With fixed-base structure, when earthquake happens, horizontal relative displacement between two stories is large. Hence, the risk of structural damage is high. Conversely, with base isolated structures, the superstructure is completely a rigid body and the inter-story drift of structure is significantly reduced. Base isolated structures will maintain the behavior in the elastic or near elastic region, and ensure that the structure is not damaged, as illustrated in Figure 1 [14].

SFP bearing - a popular device used seismic base-isolation technology in recent years, is first introduced in 1987 by Zayas [15]. It is made of stainless steel and it has a geometrical structure as shown in Figure 2. The bearing consists of an articulated slider sliding on a curved surface with radius $R$. On the curved surface and slider are covered a layer of Teflon material, so the coefficient of friction between them is very small (from $1 \%$ to $15 \%$ ). The radius $R$ in combination with the total weight of the superstructure $W$ provides a horizontal stiffness of the bearing and restoring force to move the slider to the central position. At the same time, the friction coefficient of the bearing provides the initial horizontal 
stiffness to stabilize the bearing and dissipate a part of the earthquake energy when sliding occurs. The horizontal displacement capacity of the SFP bearing is $d$, as shown in Fig. 2(b). The radius of the curved surface and coefficient of friction are important technical parameters of the bearing which decide the behavior of the bearing and the structure.

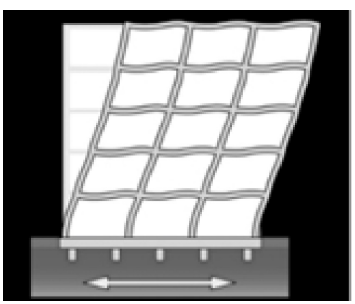

(a)

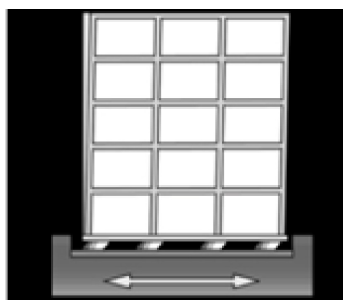

(b)

Figure 1. Building subjected to earthquake excitation. (a) Non-isolated building, (b) Isolated building

With this structure, the SFP bearing can be considered an improved type with many more advantages than previous types such as: rubber bearing, flat sliding bearing. The advantages include: durability and stability over time, resilience to the center at the end of earthquakes and easy adjustment to the technical parameters in the design.

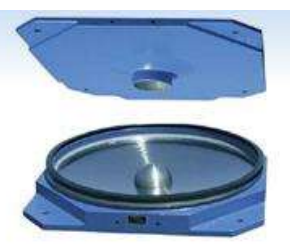

(a)

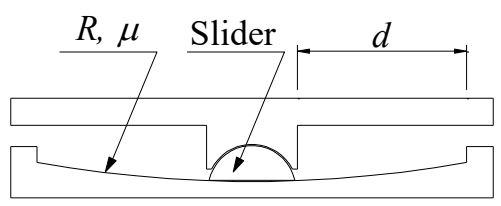

(b)

Figure 2. Single friction pendulum (SFP) bearing. (a) Cutaway view, (b) Cross section

\section{MODELING OF BASE-ISOLATED BUILDINGS WITH SFP BEARING}

\subsection{Force and horizontal displacement relationship of SFP bearing}

The movement of bearing are described in detail in study of Zayas et al. (1987) [15]. When the ground motion is weak, and the horizontal force in the bearing $F$ is smaller than the friction force between the slider and the curved surface $F_{f}$, the sliding doesn't occurs. The base isolated structure, therefore, behaves like fixed base structure. Then the SFP bearing doesn't work, as shown Figure 3(a). When the ground motion is strong enough, the force $F$ exceeds the friction force $F_{f}$, the sliding occurs, as shown Figure 3(b). During the motion, if the horizontal displacement $u$ exceeds the displacement capacity of the bearing $d$, the circumferential hard boundary prevents the bearing displacement. The impact force $F_{r}$ is provided to prevent sliding. The force components and horizontal displacements are shown in Figure 3. When the horizontal displacement of the slider is $u$, the relationship of force and horizontal displacement of the bearing is established on the basis of the force balance.

Considering equilibrium of the horizontal and vertical force at horizontal displacement $u$ of the slider, the following relationships are obtained as follows, respectively:

$$
\begin{aligned}
& F=F_{n} \sin \theta+F_{f} \cos \theta \\
& W=F_{n} \cos \theta-F_{f} \sin \theta
\end{aligned}
$$

where $F_{n}$ is the reaction force from curved surface to slider, the friction force component is $F_{f}$ and $\theta$ is the rotation angle of slider. They are determined by the following Equation (2) and Equation (3)

$$
\begin{aligned}
& F_{f}=\mu F_{n} \\
& \sin \theta=\frac{u}{R}
\end{aligned}
$$




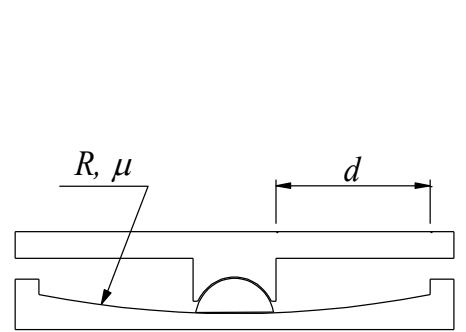

(a)

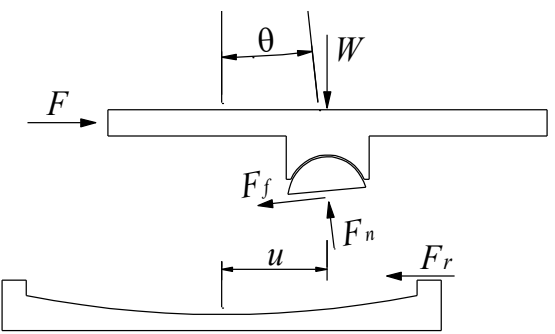

(b)

Figure 3. Single friction pendulum bearing. (a) Central location, (b) Displacements $u$ location

It is assumed that the displacement $u$ is sufficiently small compared to the radius $R$ so that the rotation angle $\theta$ is very small, approximately: $\mu \sin \theta=0$ và $\cos \theta=1$ and Equation (1) can be written as:

$$
F=\frac{W}{R} u+\mu W
$$

In Equation (4), the $(W u / R)$ component is the restoring force. Accordingly, the horizontal stiffness $k_{b}$ of the SFP bearing is computed as follows:

$$
k_{b}=\frac{W}{R}
$$

And the natural period of the SFP is determined by:

$$
T_{b}=2 \pi \sqrt{\frac{m}{k_{b}}}=2 \pi \sqrt{\frac{W}{g k_{b}}}=2 \pi \sqrt{\frac{R}{g}}
$$

When the horizontal displacement $u$ is greater than $d$, the slider will contact horizontal displacement capacity of the SFP bearing, the impact force inside the bearing $F_{r}$ happens, it's expressed as follows [5]:

$$
F_{r}=k_{r}(|u|-d) \operatorname{sign}(u) H(|u|-d)
$$

where $H$ is the value of the Heaviside step function, $k_{r}$ is the impact stiffness after contacting the maximum horizontal displacement which should be assigned a large value.

The friction force on the bearing surface is governed by a modified Bouc-Wen model and is described by Constantinou et al. [2], [7]. Equation (2) is rewritten as following Equation (8) to determine the friction force component

$$
F_{f}=\mu W Z
$$

where $\mathrm{Z}$ is dimensionless hysteretic variable which describes the friction coefficient that changes as the velocity of the slider decreases to 0 and changes the sliding direction. The hysteretic variable $Z$ is governed by the differential Equation (9)

$$
Y \dot{Z}+\gamma|\dot{u}| Z|Z|^{\eta-1}+\beta \dot{u} Z^{\eta}-A \dot{u}=0
$$

where $Y$ is the yield displacement, and $A, \beta, \gamma$ and $\eta$ are dimensionless constants and are determined from the experiment that control the shape of the hysteretic loop. These quantities can be specified as suggested by Constantinou et al [2], [7]: $Y=0.25 \mathrm{~mm}$ is the yield displacement, $A=1, \beta=0.1, \eta=2$ and $\gamma=0.9$ are the dimensionless quantities that control the shape of hysteresis loop. The velocity dependence of the coefficient of friction is described by [2]

$$
\mu=\mu_{\max }-\left(\mu_{\max }-\mu_{\min }\right) e^{-\alpha|u|}
$$

where $\mu_{\max }$ and $\mu_{\min }$ are the sliding friction coefficients at maximum velocity and nearly zero sliding velocity, respectively, $\alpha(\mathrm{s} / \mathrm{m})$ is a rate parameter for various conditions of Teflon-steel interface and pressure that controls the transition from $\mu_{\max }$ and $\mu_{\min }$ and $\dot{U}$ is the sliding velocity.

Applying friction force, impact force and modify Equations (1a) and (1b), the equation governing the force- horizontal displacement relationship of bearing as shown following Equation (11)

$$
F=\frac{W}{R} u+\mu W Z+F_{r}
$$


The hysteresis loop is shown in following Figure 4.

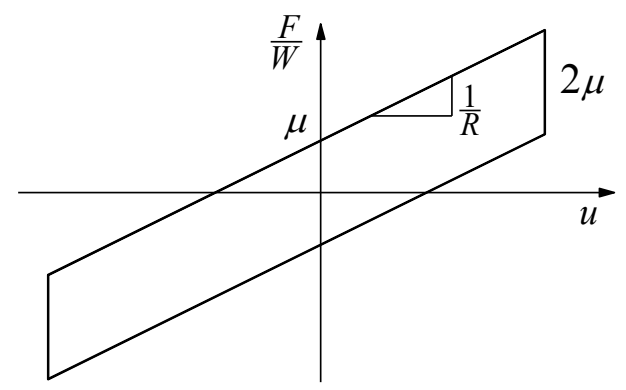

Figure 4. Hysteresis loop of SFP bearing

\subsection{Modeling of seismic isolated structure with SFP bearing}

The model of an $n$-story building is isolated by the SFP bearing. The floor slab can be considered to be an absolutely rigid body and the rotational displacement effect is ignored. Considering a 1D model, each story has one degree of freedom with the physical characteristics of: mass $m_{i}$, stiffness $k_{\mathrm{i}}$, damping coefficient $c_{i}$ and motion characteristics of: displacement $u_{i}$, velocity $\dot{u}_{i}$ and acceleration $\ddot{u}_{i}$. The numerical model of bearing is an element with a combination of a spring element, friction element and gap element in parallel. The linear spring stiffness $k_{b}$ governed by Equation (5), friction element with friction coefficient $\mu$ governed by Equation (10) and gap element governed by displacement limit $d$. The numerical model of base isolated structure has $(n+1)$ degrees of freedom and is shown in Figure 5.

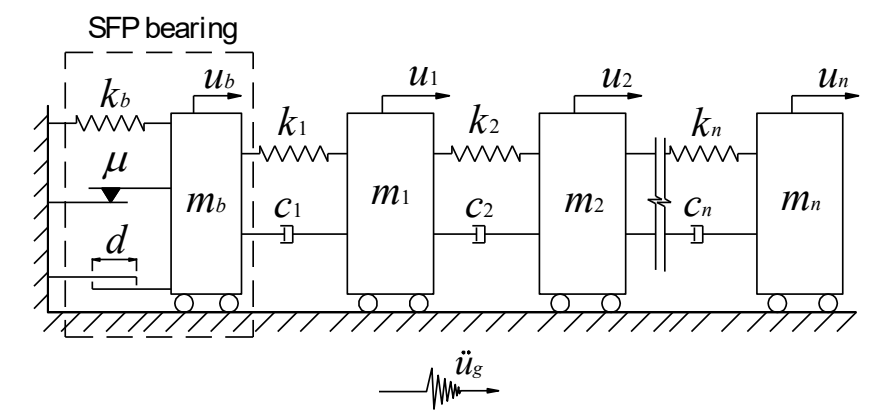

Figure 5. The model of seismic isolated structure with SFP bearing

Mass $m_{b}$ is the total mass of story above the bearing. It includes: base mass and equivalent to the mass of a floor.

Write the dynamic equation for each mass according to the D'Alembert principle, the equations of motion for model including $(n+1)$ equations can be expressed by:

$$
\left\{\begin{array}{l}
m_{b}\left(\ddot{u}_{b}+\ddot{u}_{g}\right)+k_{b} u_{b}+F_{f}+F_{r}+k_{1}\left(u_{b}-u_{1}\right)+c_{1}\left(\dot{u}_{b}-\dot{u}_{1}\right)=0 \\
m_{1}\left(\ddot{u}_{1}+\ddot{u}_{g}\right)+k_{1}\left(u_{1}-u_{b}\right)+c_{1}\left(\dot{u}_{1}-\dot{u}_{b}\right)+k_{2}\left(u_{1}-u_{2}\right)+c_{2}\left(\dot{u}_{1}-\dot{u}_{2}\right)=0 \\
\cdots \\
m_{n}\left(\ddot{u}_{n}+\ddot{u}_{g}\right)+k_{n}\left(u_{n}-u_{n-1}\right)+c_{n}\left(\dot{u}_{n}-\dot{u}_{n-1}\right)=0
\end{array}\right.
$$

where the friction force $F_{f}$ is determined by Equation (8) and impact force $F_{r}$ is determined by Equation (7) at $u=u_{b}$.

The motion differential Equations (12) is solved by the fourth-order Runge-Kutta numerical method, using the ode15s function in Matlab [12] to find the results of the time-history analysis. 


\section{NUMERICAL EXAMPLE}

To illustrate the behavior of a structure seismically isolated by SFP bearing subjected to earthquake and evaluate seismic effectiveness of SFP bearing for construction in Vietnam, an analysis of a mid-rise steel building subjected to ground motion acceleration records with ground conditions in Hanoi is implemented.

\subsection{Parameters of the structure and SFP bearing}

The structure of the analysis is a 5-storey steel building with the structural parameters as shown in Table 1 . The damping ratio $\xi=2,5 \%$ is taken from the steel material. This structure is taken from the fullscale experimental model of Ryan et al. [11]. It is compatible with seismic base isolation technology and can represent many similar constructions.

Table 1. Parameters of the structure.

\begin{tabular}{|l|c|c|c|c|c|}
\hline Story & 1 & 2 & 3 & 4 & 5 \\
\hline Mass $\left(\mathrm{kN} . \mathrm{s}^{2} / \mathrm{mm}\right)$ & 0.0824 & 0.0814 & 0.0811 & 0.0801 & 0.1199 \\
\hline Stiffness $(\mathrm{kN} / \mathrm{mm})$ & 131 & 105 & 93.3 & 76.2 & 61.1 \\
\hline
\end{tabular}

The parameters of the bearing are chosen on the basis of assumptions with reference from previous studies. It is in accordance with structural and ground conditions at site. These parameters are chosen as follows: $R=3000 \mathrm{mmm} ; \mu=0.02-0.04 ; d=500 \mathrm{~mm}$.

\subsection{Selecting and scaling ground motions}

With the ground condition, according to the forecasts, earthquake in Hanoi is Level 8 followed by the Earthquake Magnitude Scale. According to Vietnam Standards TCVN 9386:2012, the design ground acceleration is taken $a_{g}=0.24 \mathrm{~g}$ for ground types D (with the parameters: $v_{s, 30}<180 \mathrm{~m} / \mathrm{s}$ and NSPT $<15$ blows $/ 30 \mathrm{~cm}$ ) [13], and the values of the periods $T_{b}, T_{c}$ and $T_{d}$ and of the soil factor $S$ describing the shape of the elastic response spectrum are determined: $S=1.35 ; T_{b}=0.2 ; T_{c}=0.8$ và $T_{d}=2$ [13]. Figure 6 illustrates the elastic response spectra for ground types $\mathrm{D}$.

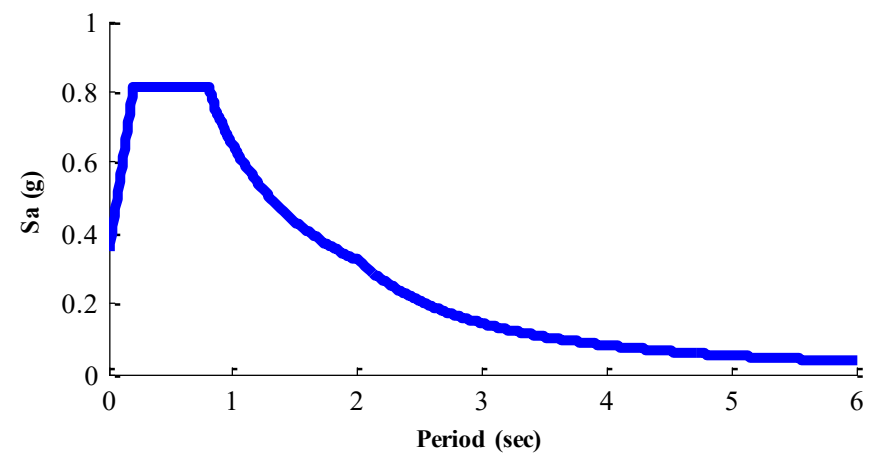

Figure 6. Elastic response spectra for ground types D

The selection and scale of the magnitude of ground motion acceleration records in the time-history analysis is guided in ASCE 7-2010 (Section 17.3.2) [9] and is detailed by Naeim and Kelly [8]. Accordingly, the number of ground motion records is seven and the average value analysis will be selected as the design criteria. In this study, the seven motion records selected from the The Pacific Earthquake Engineering Research Center (PEER) at the University of California, Berkeley [9], it is summarized in Table 2. These motions are recorded on ground types D.

The seven records will be multiplied by the $S F$ factor to scale the average response spectrum matches the target spectrum according to Standards as shown in Fig. 6. The $S F$ factor is calculated as follows [3] 


$$
S F=\frac{\int_{T_{1}}^{T_{2}} S_{a G} \cdot S_{a C} \cdot d T}{\int_{T_{1}}^{T_{2}} S_{a G}^{2} d T}
$$

where $S_{a G}$ and $S_{a C}$ are response spectrum of motion and the target spectrum, respectively. $T_{1}$ to $T_{2}$ is effective periods range, is defined: with fixed-base structure $T_{1}=0.2 T_{f}, T_{2}=1.5 T_{f}$ where $T_{f}$ is the natural period of the structure in the fundamental mode, with base isolated structure $T_{1}=0.5 T_{b} ; T_{2}=1.25 T_{b}$ where $T_{b}$ is the natural period of the base isolated structure.

Table 2. Ground motions for the analyses.

\begin{tabular}{|c|c|l|c|l|c|c|c|c|}
\hline No. & $\begin{array}{c}\text { Record } \\
\text { Seq. \# }\end{array}$ & \multicolumn{1}{|c|}{ Event (ID) } & Year & \multicolumn{1}{|c|}{ Station } & $M_{w}$ & $R_{\text {rup }}(\mathrm{km})$ & $\begin{array}{c}V_{s, 30} \\
(\mathrm{~m} / \mathrm{s})\end{array}$ & $\begin{array}{c}P G A \\
(\mathrm{~g})\end{array}$ \\
\hline 1 & 326 & Coalinga-01 (PAC) & 1983 & Parkfield - Cholame 2WA & 6.36 & 44.72 & 173.02 & 0.110 \\
\hline 2 & 334 & Coalinga-01 (PAF) & 1983 & Parkfield - Fault Zone 1 & 6.36 & 41.99 & 178.27 & 0.143 \\
\hline 3 & 718 & $\begin{array}{l}\text { Superstition Hills-01 } \\
\text { (IVW) }\end{array}$ & 1987 & $\begin{array}{l}\text { Imperial Valley Wildlife } \\
\text { Liquefaction Array }\end{array}$ & 6.22 & 17.59 & 179 & 0.133 \\
\hline 4 & 729 & $\begin{array}{l}\text { Superstition Hills-02 } \\
\text { (SUH) }\end{array}$ & 1987 & $\begin{array}{l}\text { Imperial Valley Wildlife } \\
\text { Liquefaction Array }\end{array}$ & 6.54 & 23.85 & 179 & 0.179 \\
\hline 5 & 759 & Loma Prieta (FOC) & 1989 & Foster City - APEEL 1 & 6.93 & 49.94 & 116.35 & 0.257 \\
\hline 6 & 962 & $\begin{array}{l}\text { Northridge-01 } \\
\text { (WAT) }\end{array}$ & 1994 & Carson - Water St & 6.69 & 49.81 & 160.58 & 0.092 \\
\hline 7 & 2715 & $\begin{array}{l}\text { Chi-Chi, Taiwan-04 } \\
\text { (CHY) }\end{array}$ & 1999 & CHY047 & 6.2 & 38.62 & 169.52 & 0.139 \\
\hline
\end{tabular}

With the structure above, we calculate $T_{f}=0.68 \mathrm{~s}, T_{b}$ is assumed to be about $2.7 \mathrm{~s}$. This value will be checked after having the analysis results. If it is not satisfied, must be assumed again. The results of response spectrum of 7 records for 2 cases: fixed-base and base isolated structure are shown in Figure 7.

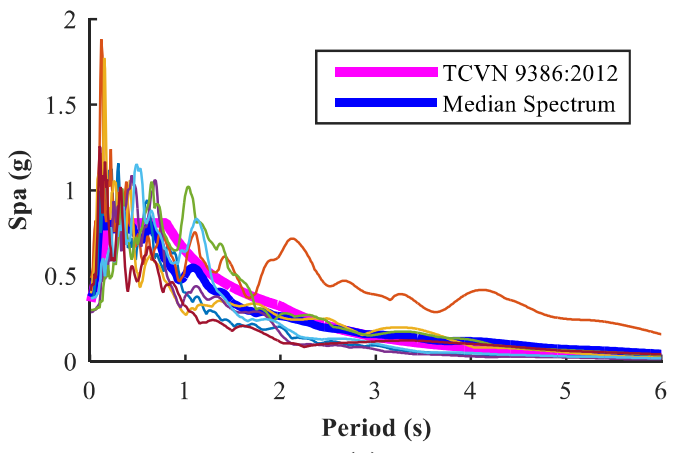

(a)

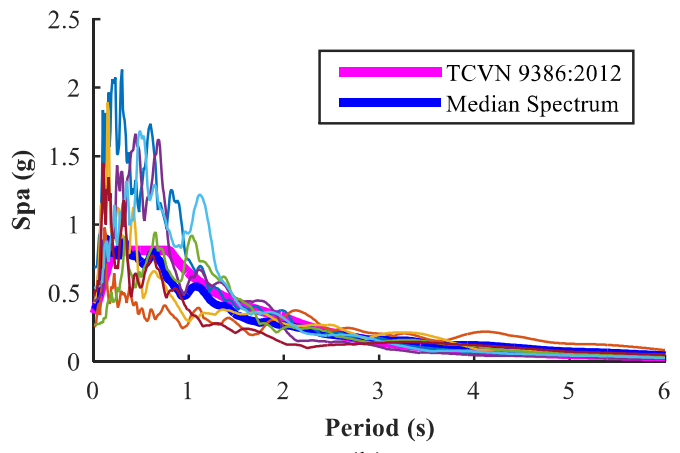

(b)

Figure 7. Target spectra compare to the median. (a) Fixed-base structure, (b) Base isolated structure

\subsection{Analysis results}

The Equations (12) present for the case of the base isolated structure. With the case of the fixed-base structure, the differential equations of motion are established similarly, it only consists of $n$ equations (in this case, no mass $m_{b}$ ). The dierential equations are resolved numerically using the Runge-Kutta method. However, for computational efficiency, the equations will be converted into the first order differential equations and solved by ODE functions (ode15s solver) that are introduced in the research of Shampine et al. [12]. Accordingly, the results for the time history analysis of structure for two cases subjected to the seven ground accelerations are determined accurately. The average results are used to evaluate the behavior of the structure and the bearing.

Analytical values include: absolute acceleration of each floor, story shear force, total base shear and 
displacement of the bearing for two cases, and the effectiveness of the isolation system. These results are listed in Table 3.

The maximum absolute acceleration of each floor and the story shear forces of structure are shown in Figure 8. The data for this figure is the average value from 7 analysis.

The value of shear force in the 1st and 5st story in the time history analysis for two cases with IVW motion are shown in Figures 9 and 10. Similarly absolute acceleration are shown in Figures 11 and 12.

The hysteresis loops represents the force - horizontal displacement relationship of the bearing is shown in Figure 13.

Figure 9 to 13 show the results of the analysis for IVW motion. With others, the results are similar, not shown here.

Table 3. Isolation performance evaluation of SFP bearing.

\begin{tabular}{|c|c|c|c|c|c|c|c|c|c|c|c|}
\hline \multirow{2}{*}{\multicolumn{2}{|c|}{ Story }} & \multicolumn{2}{|c|}{1} & \multicolumn{2}{|c|}{2} & \multicolumn{2}{|c|}{3} & \multicolumn{2}{|c|}{4} & \multicolumn{2}{|c|}{5} \\
\hline & & \multirow{2}{*}{$\begin{array}{l}\text { Val. } \\
0.57\end{array}$} & \multirow{2}{*}{$\begin{array}{c}\begin{array}{c}\text { Red. } \\
(\%)\end{array} \\
54\end{array}$} & \multirow{3}{*}{$\begin{array}{c}\text { Val. } \\
0.93 \\
0.23\end{array}$} & \multirow{2}{*}{$\begin{array}{r}\text { Red. } \\
(\%)\end{array}$} & \multirow{2}{*}{$\begin{array}{l}\text { Val. } \\
1.31\end{array}$} & $\begin{array}{l}\text { Red. } \\
(\%)\end{array}$ & \multirow{2}{*}{$\frac{\text { Val. }}{1.64}$} & $\begin{array}{c}\text { Red. } \\
(\%)\end{array}$ & \multirow{2}{*}{$\begin{array}{l}\text { Val. } \\
1.96\end{array}$} & $\begin{array}{l}\text { Red. } \\
(\%)\end{array}$ \\
\hline \multirow{2}{*}{$\begin{array}{l}\text { Abs. acc. } \\
(\mathrm{g})\end{array}$} & Fixed & & & & & & \multirow{2}{*}{82} & & \multirow{2}{*}{86} & & \multirow{2}{*}{86} \\
\hline & Isolated & 0.26 & 54 & & 15 & 0.24 & & 0.23 & & 0.28 & \\
\hline \multirow{2}{*}{$\begin{array}{c}\text { Inter. shear } \\
\left(.10^{3} \mathrm{kN}\right)\end{array}$} & Fixed & 5.44 & \multirow{2}{*}{91} & 5.11 & \multirow{2}{*}{90} & 4.48 & \multirow{2}{*}{90} & 3.54 & \multirow{2}{*}{89} & 2.30 & \multirow{2}{*}{86} \\
\hline & Isolated & 0.47 & & 0.49 & & 0.46 & & 0.40 & & 0.33 & \\
\hline \multirow{2}{*}{$\begin{array}{c}\text { Base shear } \\
\left(.10^{3} \mathrm{kN}\right)\end{array}$} & Fixed & \multicolumn{10}{|c|}{5.41} \\
\hline & Isolated & \multicolumn{10}{|c|}{0.47 (Reduce: $91 \%$ ) } \\
\hline \multirow{2}{*}{$\begin{array}{l}\text { Base displ. } \\
(\mathrm{cm})\end{array}$} & Fixed & \multicolumn{10}{|c|}{0} \\
\hline & Isolated & \multicolumn{10}{|c|}{17.3} \\
\hline
\end{tabular}

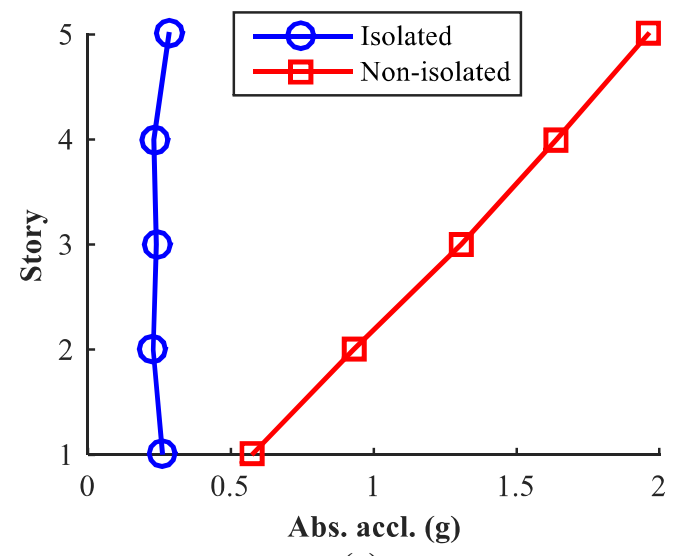

(a)

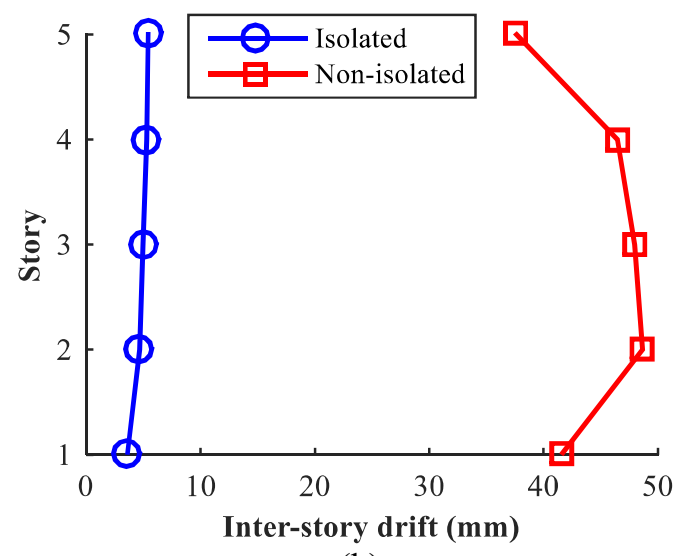

(b)

Figure 8. Seismic effectiveness of SFP bearing. (a) Absolute acceleration of each story, (b) Inter-story drift

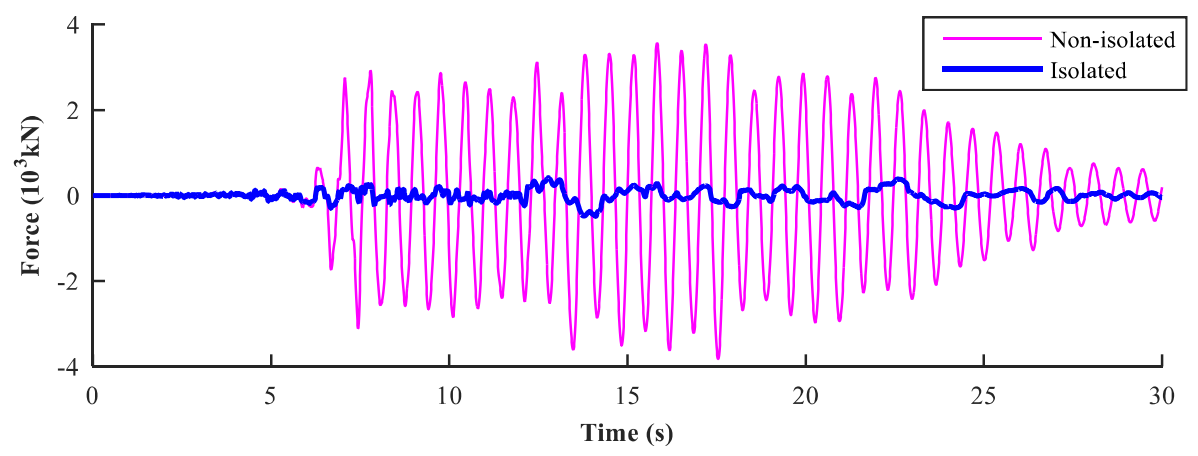

Figure 9. Shear force of 1st story with IVW motion. 


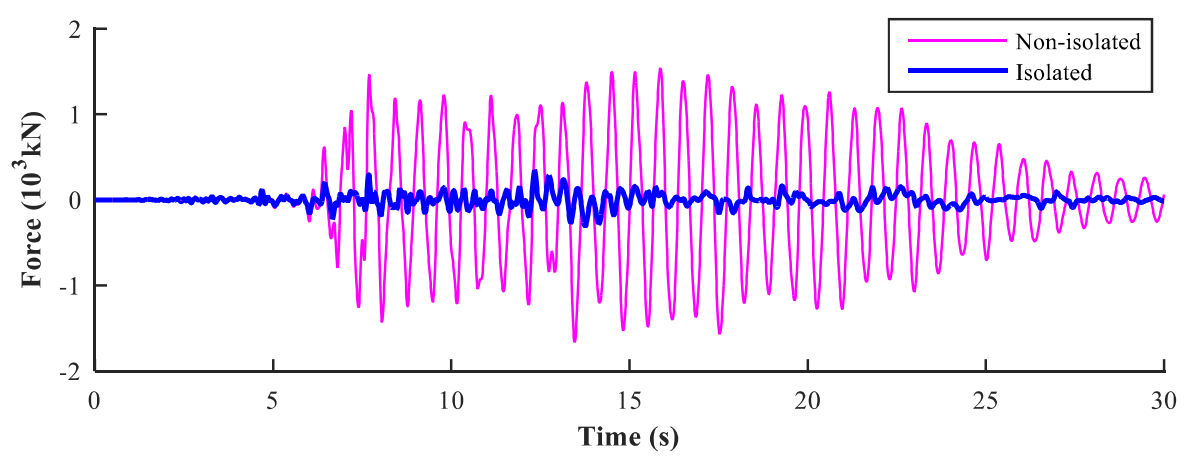

Figure 10. Shear force of 5st story with IVW motion.

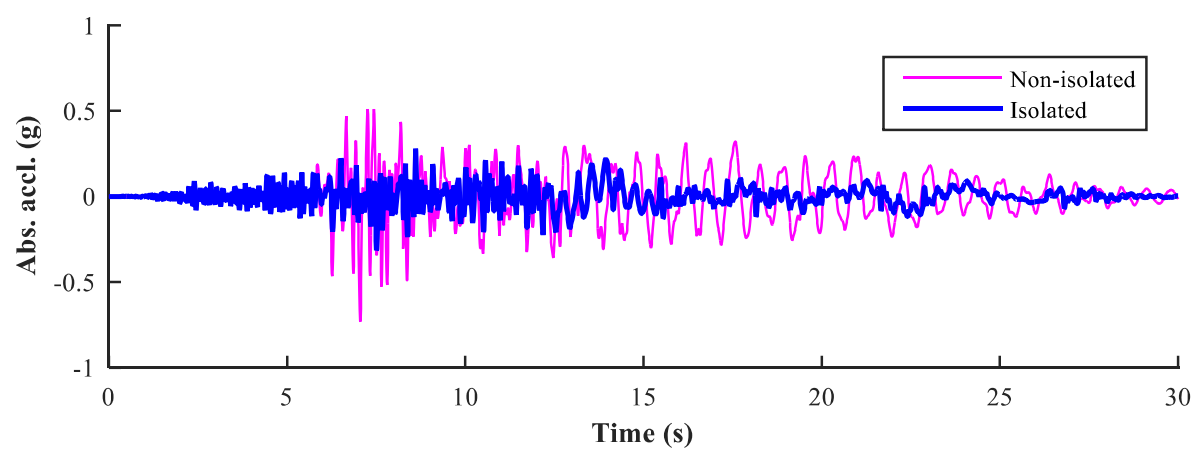

Figure 11. Absolute acceleration of 1st story with IVW motion.

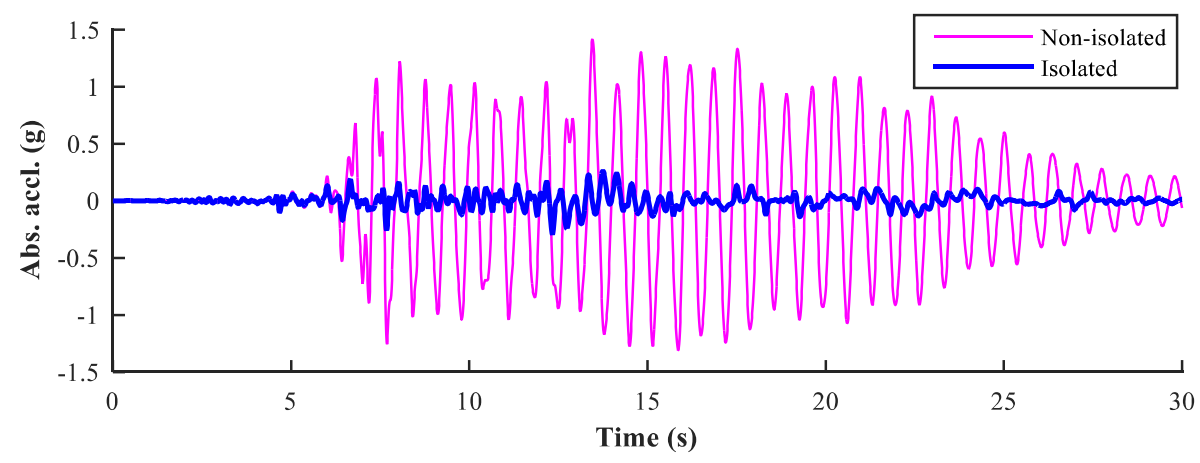

Figure 12. Absolute acceleration of 5st story with IVW motion.

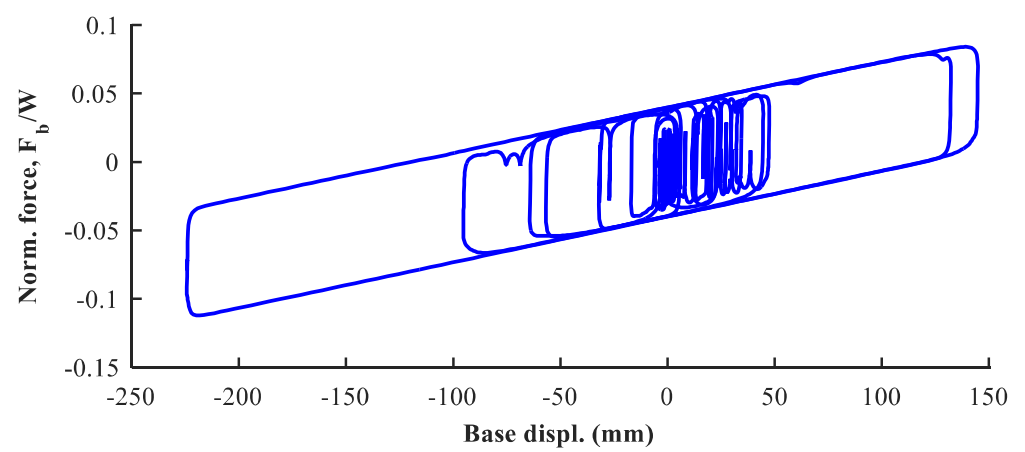

Figure 13. Hysteresis loops of bearing with IVW motion 


\subsection{Discussion}

According to the results shown in Table 3 and Figure 8, the seismic effectiveness of the SFP bearing is very high, approximately $75 \%$ for absolute acceleration and $90 \%$ for shear forces in each floor. From the result, one can calculate the effective stiffness $K_{\text {eff }}$ and effective period $T_{\text {eff }}$ of the base isolated structure for each acceleration record according to the following formulas, respectively [4]

$$
\begin{aligned}
& K_{\text {eff }}=\frac{F_{\max }}{u_{b}} \\
& T_{\text {eff }}=2 \pi \sqrt{\frac{W}{g K_{e f f}}}
\end{aligned}
$$

where $F_{\max }$ is the largest horizontal force in the bearing and $u_{b}$ is the displacement at $F_{\max }$.

The average value $T_{\text {eff }}=2.68 \mathrm{~s}$ will be compared with $T_{b}=2.7 \mathrm{~s}$ which is assumed initially. This result is slightly different, so the initial value assumptions are reasonable, it doesn't need to repeat.

The displacement of bearing $u_{b}=17.3 \mathrm{~cm}$ is the basis for choosing the size of the bearing in the design. This displacement in base isolated buildings is usually large. This is a disadvantage of this technique. Therefore, the designer should note this problem.

With the time-history results in Figures 9 and 12, the seismic effectiveness is expressed throughout the time of the earthquake. At times with small ground acceleration, the movement of the bearing still occurs and seismic effectiveness is maintained. The shape of hysteresis loops in the analytical model shown in Figure 13 is similar with the results of research of Zayas [15], as shown in Figure 4.

\section{CONCLUSIONS}

SFP bearings are effective devices to reduce the effect of earthquakes on buildings. This study developed a simple model to quickly determine the response of base isolated structures subjected to earthquakes. Through this model, a time-history analysis is implemented for a 5-storey steel building subjected to ground motion acceleration records scaled to fit the earthquake conditions in Hanoi. The results of the analysis show that SFP bearings can reduce the demand to the structure up to $80 \%$. The dynamic responses of the structure show that absolute acceleration of each story, inter-story drift and base shear significantly reduce. Therefore, the use of this bearing in the seismic resistant design in Hanoi and in Vietnam is encouraged.

\section{ACKNOWLEDGMENT}

This research is funded by Industrial University of Ho Chi Minh City for research project under Grant No. 171.1051

\section{REFERENCES}

[1] American Society of Civil Engineers, Minimum Design Load for Buildings and Other Structures, ASCE 7-10, 2010.

[2] M. Constantinou, A. Mokha and A. Reinhorn, Teflon bearings in base isolation II: Modeling, ASCE Journal of Structural Engineering, vol. 116, no. 2, pp. 455-474, 1990.

[3] N. D. Dao, Seismic Response of a Full-scale 5-story Steel Frame Building Isolated by Triple Pendulum Bearings under Three-Dimensional Excitations, University of Nevada, Reno, 2012.

[4] F. Fadi and M. Constantinou, Evaluation of simplied methods of analysis forstructures with triple friction pendulum isolators, Earthquake Engineering and Structural Dynamics, vol. 39, no. 1, pp. 5-22, 2010.

[5] D. Fenz and M. Constantinou, Spherical sliding isolation bearings with adaptive behavior: Theory, Earthquake Engineering and Structural Dynamics, vol. 37, no. 2, pp. 163-183, 2008. 
[6] Huong Thu. (2014) 27 trận động đất ở Việt Nam trong nửa năm qua. [Online]. Available: http://vnexpress.net/tin-tuc/thoi-su/27-tran-dong-dat-oviet-nam-trong-nua-nam-qua-3035027.html

[7] A. Mokha, M. Constantinou and A. Reinhorn, Teflon bearings in base isolation I: Testing, ASCE Journal of Structural Engineering, vol. 116, no. 2, pp. 438-454, 1990.

[8] F. Naeim and J. Kelly, Design of seismic isolated structures: from theory to practice, John Wiley \& Sons, 1999.

[9] Pacific Earthquake Engineering Research Center (PEER). (2017) Ground motion database. [Online]. Available: http://ngawest2.berkeley.edu.

[10] Quang Duan. (2011) Hà Nội nằm trong vùng động đất cấp 7- 8. [Online]. Available: http://thanhnien.vn/thoisu/ha-noi-nam-trong-vung-dongdat-cap-78-432322.html.

[11] K. Ryan and et al., Full scale 5-story building with triple pendulum bearings at E-Defense, Network for Earthquake Engineering Simulation, 2013.

[12] L. F. Shampine and M. W. Reichelt, The Matlab ode suite, SIAM Journal on Scientific Computing, vol. 18, no. 1, pp. 1-22, 1997.

[13] Vietnam standards, TCVN 9386:2012 Design of structures for earthquake resistance, Publisher of Construction, Hanoi, 2013.

[14] Y. P. Wang, Fundamentals of seismic base isolation, International training program for seismic design of building structures, sponsored by National Science Council, National Chiao-Tung Unversity, Hsinchu, Taiwan, 2002.

[15] V. A. Zayas, S. Low and S. A. Mahin, The FPS earthquake resisting system, Rep. No. UCB/EERC-87/01, Earthquake Eng. Res. Center, Univ. of California at Berkeley, Berkeley, California, US, 1987.

\section{HIỆU QUẢ CỦA NHŨ̉NG TÒA NHÀ CÁCH CHẤN BẦNG GỐI SFP : MỘT ÚNG DỤNG Ở VIẸT NAM}

Tóm tắt. Hiện nay, việc sử dụng kỹ thuật điều khiển dao động kết cấu trong thiết kế kháng chấn công trình ở Việt Nam còn rất hạn chế. Trong bài báo này, một đánh giá hiệu quả của việc sử dụng gối con lắc ma sát đơn (gối SFP) cho các tòa nhà cách chấn ở Việt Nam được trình bày. Phân tích theo lịch sử thời gian một mô hình $1 \mathrm{D}$ của tòa nhà 5 tầng chịu động đất được tiến hành cho 2 trường hợp: có và không có sử dụng gối SFP. Dữ liệu gia tốc nền phân tích được lựa chọn và hiệu chỉnh cho phù hợp với gia tốc nền thiết kế tại Hà Nội lấy theo TCVN 9386:2012. Úng xử động của kết cấu trong 2 trường hợp được đánh giá chi tiết. Theo kết quả phân tích, kết cấu cách chấn làm giảm $90 \%$ tổng lực cắt đáy, chuyển vị tương đối giữa các tầng và gia tốc tuyệt đối trong các tầng cũng giảm đáng kể.

Từ khóa. Kỹ thuật cách chấn đáy, gối SFP, thiết kế chịu động đất, điều khiển bị động kết cấu, điều kiện địa chấn ở Hà Nội.

Ngày nhận bài: 20/10/2017

Ngày chấp nhận đăng: 31/12/2017 